\title{
Comparative Job Satisfaction and Its Determinants in For-Profit and Nonprofit Employees Across the Globe
}

\author{
Maureen Snow Andrade \\ Utah Valley University \\ Jonathan H. Westover \\ Utah Valley University
}

\begin{abstract}
Beneficial outcomes of job satisfaction include greater productivity, higher work quality, increased company competitiveness, less turnover, and decreased workplace conflict. Understanding the variables that impact job satisfaction is critical to improving organizational effectiveness. The current research compares job satisfaction factors among for-profit and nonprofit employees globally, using International Social Survey Program data on work orientations. As such, this study contributes new insights from a large-scale international data set to inform employers and researchers about factors that contribute to job satisfaction on a global basis. Findings indicate more commonalities than differences in job satisfaction factors across the two groups.
\end{abstract}

Keywords: job satisfaction, for-profit, nonprofit, global comparisons

\section{INTRODUCTION}

Employers greatly benefit from satisfied workers; thus, it is in their best interest to identify factors that contribute to satisfaction and those that detract from it. Satisfaction in one's work equates to higher quality work (Tietjen \& Myers, 1998) and greater productivity (Appelbaum \& Kamal, 2000), both of which increase a company's competitiveness (Garrido, Perez, \& Anton, 2005). On the other hand, unsatisfied workers are more likely to demonstrate withdrawal cognitions and be late for work, absent from work, or seek other jobs (Blau, 1994; Lee, 1998). This can result in work not being performed, interpersonal issues and conflict, and increased time and expense to recruit, hire, and train new employees.

Research has explored differences in motivation for workers in for-profit and nonprofit organizations, generally concluding that the latter have higher levels of intrinsic motivation due to a desire to contribute to the greater good, serve others, or impact social change as opposed to focusing on monetary rewards (Buelens \& Van den Broeck, 2007; Borzaga \& Tortia, 2006; Boyne, 2002; Leete, 2000; Lewis \& Frank, 2002; Light, 2002; Liu \& Tang, 2011; Melnick, Petralla, \& Richez-Battesti, 2013; Narcy, 2011). In many cases, nonprofit employees also report greater opportunities in terms of self-development, task variety, challenge, and influence (Houston, 2000; Jurkiewicz \& Massey, 1997; Karl \& Sutton, 1998; Mirvis \& Hackett, 1983), all of which lead to satisfaction, workplace stability, innovation, and creativity (Mirvis \& Hackett, 1983; Garg \& Rastogi, 2006). 
However, little is known about these factors in a global context. Certainly, country-specific studies, and in some cases large-scale studies, have contributed to the knowledge base. Examples include those situated in Belgium (Buelens \& Van den Broeck, 2007), Finland (Selander \& Ruuskanen, 2016), South Africa (Renard \& Snelgar, 2016), France (Melnick et al., 2013), Korea (Kang, Huh, Cho, \& Auh, 2014), and the U.S. (Butler, 2009; Cohen, 2010), as well as comparative studies of the U.S. and UK (Benz, 2005). The current research expands on this foundation to compare job satisfaction among for-profit and nonprofit employees using International Social Survey Program data (ISSP; Work Orientations IV, 2015). The ISSP survey examines factors associated with job characteristics and job quality from employees across 37 countries. This study is the first of its kind to contribute insights from a large-scale international data set to inform employers and researchers about factors that contribute to job satisfaction on a global basis.

\section{LITERATURE REVIEW}

A number of variables have been examined to explain differences in job satisfaction across for-profit and nonprofit organizations. These include motivation, rewards, salaries, benefits, working conditions, task characteristics, autonomy, decision-making, management factors, and education-job match. Research generally indicates that job satisfaction is derived from pay and monetary rewards for for-profit employees whereas employees in nonprofit organizations derive job satisfaction from intrinsic values, such as considering one's work to be of benefit to others (Buelens \& Van den Broeck, 2007; Borzaga \& Tortia, 2006; Boyne, 2002; Leete, 2000; Lewis \& Frank, 2002; Light, 2002; Liu \& Tang, 2011; Melnick, Petralla, \& Richez-Battesti, 2013; Narcy, 2011). Job satisfaction leads to less absenteeism and turnover, easier recruitment of skilled workers, and more effective performance on both individual and organizational levels (Melnick et al., 2013). Work that is considered purposeful is characterized by similar outcomes, specifically reduced absenteeism and turnover, less dissatisfaction, cynicism, and depression, and more fulfillment, commitment, effort, and engagement (Beechler, 2013). Meaningful, or purposeful, work is characteristic in nonprofit organizations.

Job design research shows that control over one's work, flexibility, and variety are associated with motivation, which leads to innovation, creativity, and proactive performance (Garg \& Rastogi, 2006). Nonprofit employees are typically characterized by intrinsic motivation and commitment (Lanfranchi, Narcy, \& Larguem, 2009; Leete, 2002; Mirvis \& Hackett, 1983), and experience more autonomy, selfdevelopment, task variety, challenge, and influence than do for-profit employees (Houston, 2000; Jurkiewicz \& Massey, 1997; Karl \& Sutton, 1998; Mirvis \& Hackett, 1983) with some exceptions (Buelens \& Van den Broeck, 2007). These job quality characteristics are linked to satisfaction (Mirvis \& Hackett, 1983). Nonprofit workers are also motivated by opportunities to contribute to the public good in the form of service to society and the community (Boyne, 2002; Gabris \& Simon, 1995; Houston, 2000; Perry; 2000; Perry \& Wise, 1990; Preston, 1989) in order to impact social change (Brandi, 2012) and achieve social justice (Perry, 1996, 1997; Perry \& Wise, 1990).

Variety, creativity, professional development opportunities, and recognition also contribute to job satisfaction in nonprofits (Borzaga \& Tortia, 2006; Houston, 2000; Jurkiewicz et al., 1998; Karl \& Sutton, 1998) as do autonomous organizational structures such as self-directed teams, which are more characteristic of nonprofits than for-profits (Kalleberg, Marsden, Reynolds, \& Knoke, 2006). Nonprofit workers in South Africa identified intrinsic motivation as stemming from work that was purposeful, challenging, flexible, varied, and enjoyable (Renard \& Snelgar, 2016). French service sector workers determined that job satisfaction was positively impacted by professional management practices, wages, positive perceptions of the work environment, and nonprofit status (Melnick et al., 2013).

Rather than being interested in financial rewards, nonprofit employees may be motivated by organizational mission (Rose-Ackerman, 1996), or the desire to produce something of quality (Hansmann, 1980). The latter is more likely in nonprofits as they emphasize quality and customer wellbeing over profit (Weisbrod, 1998). Indeed, donative labor hypothesis suggests that individuals will accept lower wages in a nonprofit due to intrinsic motivation, the satisfaction they derive from the work 
(Benz, 2005; Cohen, 2010), a sense of altruism (Borzaga \& Depedri, 2005), or organizational emphasis on social responsibility (Frank, 1996; Sen, 1985). Some have found wages in nonprofits to be comparable with those of for-profits due to market competition (Ruhm \& Borkowski, 2003) while others have found variations (Butler, 2009). For instance, healthcare practitioner wages were similar in for-profits and nonprofits and higher than those in state and local government; in healthcare support, for-profit and nonprofit employees also had similar wages, but state government employees earned more (Butler, 2009). In other studies, employees in U.S. nonprofits were found to be paid less than those in for-profit companies and government agencies and have fewer bonuses across occupations and organizational size (Cohen, 2010). This was especially true in management level positions, where the gap is as high as $30 \%$, executives, and technical positions. In South Africa, employees in non-government organizations earn approximately $40 \%$ less than those in the private sector and about $22 \%$ less than those in international nonprofits (Renard \& Snelgar, 2016). These studies suggest variations in pay depending on the specific sector in which nonprofits operate, data set variations, as well as country contexts.

Lower wages in a nonprofit may be compensated for with non-pecuniary benefits such as greater flexibility, better relations with stakeholders, and a clearer match between education and job responsibilities (Becchetti, Castriota, \& Depedri, 2013). In fact, feelings of job safety, or a supportive, positive, congenial work environment are also associated with nonprofit employees (Buelens \& Van den Broeck, 2007; Houston, 2000; Jurkiewica et al., 1998; Lewis \& Frank, 2002). These benefits, together with intrinsic motivation, resulted in higher job satisfaction for workers who voluntarily moved from a for-profit organization to a nonprofit compared with workers who involuntarily made the same move (Becchetti et al., 2013). Another comparative study found that employees in the U.S. and the UK who worked in nonprofits were significantly more satisfied with their jobs than those in for-profit organizations, not due to salary, benefits, or working hours, but to non-pecuniary benefits such as intrinsic motivation (Benz, 2005). A third study identified that the job satisfaction of employees in human service organizations was due to intrinsic motivation, not external rewards (Selden \& Sowa, 2011). In spite of this, nonprofits cannot justify paying inequitable wages simply because the work is inherently meaningful and satisfying (Renard \& Snelgar, 2016). In fact, nonprofits may need to exhibit greater wage equity in order to maintain employee motivation (Leete, 2000).

Nonprofit employees have been found to have higher stress and workloads, yet are more satisfied with their work than those in for-profit organizations (Mirvis \& Hackett, 1983). Although nursing home employees in non-profit organizations reported heavier workloads and higher stress than those in forprofits, they did not have lower job satisfaction (Hamaan \& Foster, 2014). Higher stress levels for these employees may have actually been due to their intrinsic motivation, which influenced them to work harder for those they assisted and become emotionally involved. Nonprofit employees did not enjoy greater decision making or more social support than their for-profit counterparts, factors which could have increased job commitment and satisfaction. Human services workers in childcare and child welfare, youth services, juvenile justice, and employment training value their roles and strongly desire to help others, but "heavy workloads, long hours, turnover, uneven access to resources, inconsistent rewards, and a lack of community support render their jobs unappreciated and frustrating" (Light, 2003, p. 7).

Similarly, Finnish nonprofit workers had more turnover intentions than those in for-profit organizations due to poor job quality (work climate, lack of advancement opportunities, lack of opportunity to use skills) although those who shared values with the organization expressed a desire to stay in their jobs (Selander \& Ruuskanen, 2016). Additionally, managers in nonprofits have challenges in recruiting and retaining employees in some contexts due to lower salaries and fewer opportunities for promotion (Ban, Drahnak-Faller, \& Tower, 2003; Brown \& Yoshioka, 2003; Kang, Huh, Cho, \& Auh, 2014; Kim \& Lee 2007). For example, in Korea, over half of the community college and university graduates studied left nonprofits within a year and most moved to for-profit organizations (Kang et al., 2015). In other cases, in spite of commitment to organizational mission, dissatisfaction with working conditions resulted in employee turnover (Kim \& Lee, 2007). These findings illustrate that working conditions can vary widely across nonprofits and support the importance of nonprofit employees having a 
strong public service motivation and conditions conducive to making their work meaningful and manageable.

Education-job match enhances job satisfaction for nonprofit and for-profit workers; however, when a poor match occurs, lower job satisfaction may be ameliorated by higher salaries for those in the for-profit sector (Lee \& Sabharwal, 2016). Those in nonprofit sectors are more likely to experience education-job match than those in for-profit firms, but women in these sectors report lower job satisfaction (Lee \& Sabharwal, 2016). This is supported by the findings of a study in which for-profit employees moved to nonprofit organizations and experienced better education-job fit, relationships with colleagues (particularly for women; Buelens \& Van den Broeck, 2007), and time flexibility (Becchetti et al., 2013). Job training enhances satisfaction for for-profit employees (Lee \& Sabharwal, 2016).

Education-job match furthers job satisfaction overall as it enables workers to put their knowledge and skills to use (Allen \& Van der Velden, 2001) while a mismatch decreases satisfaction (Vila \& GarciaMora, 2005). While the literature comparing nonprofit and for-profit sectors indicates that workers in the two former categories are more likely to be motivated by intrinsic rewards as the result of opportunities for self-fulfillment and societal contributions (Borzaga \& Tortia, 2006; Light, 2008), education-job match is an additional factor that must be considered. Gender, age, and educational levels do not appear to impact motivation in either organizational type (Crewson, 1997; Jurkiewica, 2000; Kacmar, Carlson, \& Brymer, 1999) with some exceptions indicating that older workers have fewer turnover intentions, place greater value on a supportive work environment, and are less motivated by salary than their younger counterparts (Buelens \& Van den Broeck, 2007).

A factor that has demonstrated differences in motivation for public and non-profit employees is hierarchical level, particularly as it relates to job commitment. Findings are mixed in terms of commitment at management levels with some studies indicating less commitment for nonprofit managers (Balfour \& Wechsler, 1991; Boyne, 2002; Moon, 2000; Rainey, 1989) and others indicating greater commitment at the management level (Buelens \& Van den Broeck, 2007; Farid, 1997; Goulet \& Frank, 2002; Zeffane, 1994) and also for workers (Buelens \& Van den Broeck, 2007) or no differences (Baldwin, 1991). Commitment is defined as willingness to work long hours; generally, for-profit sector employees in these studies have scored lower in this regard than nonprofit. In spite of greater commitment to work, however, nonprofit employees have also been shown to experience less work-family conflict than their for-profit counterparts (Buelens \& Van den Broeck, 2007).

This review finds partial support for Herzberg's $(1966,1968)$ two-factor motivation theory, namely that factors leading to job satisfaction are distinct from those causing dissatisfaction. The theory posits that factors leading to satisfaction are intrinsic such as achievement, responsibility, advancement, recognition, and the work itself while extrinsic factors such as work conditions, relationships with coworkers and managers, supervision, and salary can lead to dissatisfaction, but do not create satisfaction. The findings reviewed here indicate that some external factors, such as relationships, time flexibility, and education-job fit, do lead to satisfaction. Findings also support self-determination theory, which proposes that intrinsic motivation increases when employees have autonomy, opportunities to develop job competence, and positive connections to others (Ryan \& Deci, 2000).

Generally speaking, nonprofit job roles may not be specifically designed to encourage intrinsic motivation. Rather the features that promote this motivation such as job meaningfulness, autonomy, connectedness, decision-making, organizational mission, and professional management practices are typically embedded in the culture of nonprofits. Historical, cultural, and contextual issues indicate varied practices in this area and comparative salary studies have dissimilar findings. Managers in nonprofits should be aware of factors that support intrinsic motivation and ensure that these characteristics are maintained or enhanced so that employees will continue to enjoy and value their work. Managers should also consider that education-job fit is important to recruiting for nonprofits while stress and overwork must be addressed in terms of employee well-being. Additionally, work-life balance is a critical consideration in that strong work commitment and high levels of organizational citizenship behavior may be detrimental to family life although findings on this vary. 


\section{THEORETICAL FRAMEWORK AND MODEL}

As depicted in Figure 1 below, we utilize a job satisfaction theoretical model developed by Andrade and Westover's (2018a, 2018b), which combines the literature to date in job satisfaction and its determinants. Similar to many previous studies, we include important intrinsic, extrinsic, work relations, work-life balance, and organizational and job characteristics control variables. Additionally, and most germane to this current research, we include a for-profit/nonprofit control variable in the analysis to explore differences in the model based on the type of organization an employee works in.

\section{RESEARCH DESIGN AND METHODOLOGY}

As noted, research has determined that nonprofit employees possess high levels of intrinsic motivation derived from factors such as opportunities for self-fulfillment and contributions to society (Borzaga \& Tortia, 2006; Light, 2008). Having a safe, supportive, positive, and congenial work environment is also important to nonprofit employees (Buelens \& Van den Broeck, 2007; Houston, 2000; Jurkiewica et al., 1998; Lewis \& Frank, 2002). Other work-life balance and work relations elements salient to nonprofit workers include job and time flexibility, fewer work-family conflicts, and greater connectedness with others; these factors may also compensate for lower wages (Becchetti, Castriota, \& Depedri, 2013; Buelens \& Van den Broeck, 2007).

FIGURE 1

FACTORS INFLUENCING WORK CHARACTERISTICS AND JOB SATISFACTION

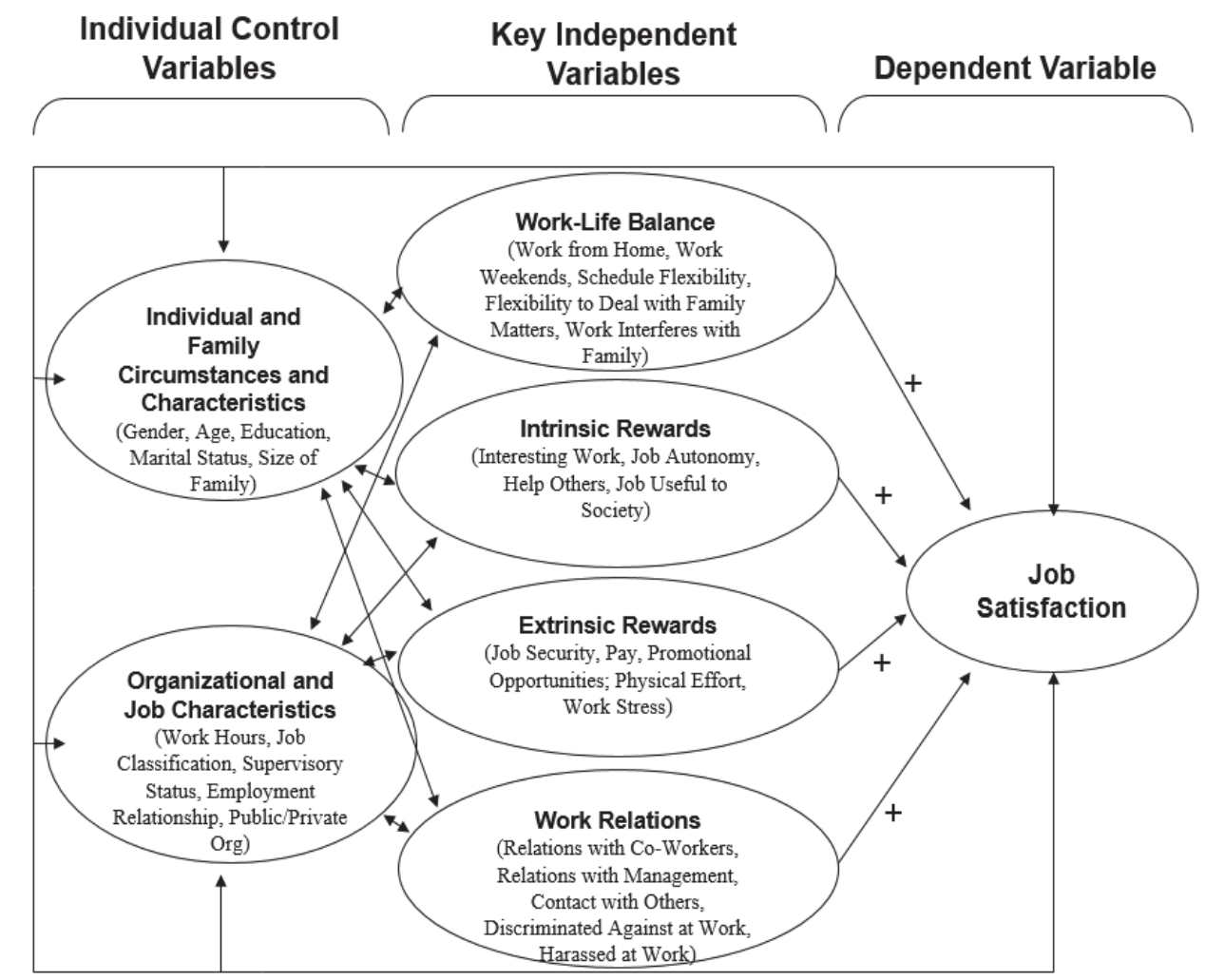




\section{Hypotheses}

Given previous research findings on job satisfaction for for-profit and nonprofit workers, the hypotheses for this study are as follows:

\section{Job Satisfaction by For-Profit and Nonprofit Organizations}

H1: There will be consistent statistically significant international differences in job satisfaction levels for for-profit and nonprofit employees, controlling for other work characteristic and individual factors.

Job Satisfaction Determinants by For-Profit and Nonprofit Organizations

H2a: Extrinsic characteristics are more salient and provide a greater level of predictability in job satisfaction levels for for-profit workers than their nonprofit counterparts.

H2b: Intrinsic characteristics will be more salient and provide a greater level of predictability in job satisfaction levels for nonprofit workers than their for-profit counterparts.

H2c: Work relations will be more salient and provide a greater level of predictability in job satisfaction levels for nonprofit workers than their for-profit counterparts.

H2d: Work-life balance characteristics will be more salient and provide a greater level of predictability in job satisfaction levels for nonprofit workers than their for-profit counterparts.

\section{Description of the Data}

Following the approach of Andrade and Westover (2018a; 2018b), this research utilizes the International Social Survey Program (ISSP) 2015 Work Orientations Module IV ${ }^{1}$, which uses multistage stratified probability samples in 37 individual countries ${ }^{2}$. As Westover noted, "The International Social Survey Program Work Orientations modules utilized a multistage stratified probability sample to collect the data for each of the various countries with a variety of eligible participants in each country's target population" (2012a, p. 3). The ISSP 2015 Work Orientations IV module focuses on work characteristics and experiences of employees in the workplace across the globe. All ISSP variables are single-item indicators (i.e. with a single survey question for each variable on a Likert scale). The unit of analysis is individuals within the separate sovereign nations. We examine one large sample with all respondents across the globe, as well as a separate sample for both for-profit and nonprofit organization employees to explore the job characteristics that best predict job satisfaction for each group and then make comparisons (2012a, p. 3).

\section{Operationalization of Variables}

We use Andrade and Westover's (2018a, 2018b) job satisfaction model (building on Handel's (2005) and Kalleberg's (1977) job satisfaction model, for comparing global differences in job satisfaction and its determinants (see also Spector 1997; Souza-Poza \& Souza-Poza 2000; Munoz de Bustillo Llorente \& Macias, 2005). Following the approach of Andrade and Westover's (2018a, 2018b), we focused on a range of intrinsic, extrinsic, workplace relationships, and work-life balance variables (in addition to a range of organization and individual control variables; Table 1 below $^{3}$ ). 
TABLE 1

KEY CHARACTERISTICS RELATED TO JOB SATISFACTION

\author{
Dependent Variable: \\ Job Satisfaction $^{4}$ \\ Intrinsic Rewards ${ }^{5}$ : \\ Interesting Job \\ Job Autonomy \\ Help Others \\ Job Useful to Society \\ Extrinsic Rewards ${ }^{6}$ : \\ Pay \\ Job Security \\ Promotional Opportunities \\ Physical Effort ${ }^{7}$ \\ Work Stress $^{8}$ \\ Work Relations: \\ Management-Employee Relations ${ }^{9}$ \\ Coworker Relations ${ }^{10}$ \\ Contact with Others ${ }^{11}$ \\ Discriminated against at Work $^{12}$
}

Harassed at Work ${ }^{13}$

\section{Work-Life Balance}

Work from Home ${ }^{14}$

Work Weekends ${ }^{15}$

Schedule Flexibility ${ }^{16}$

Flexibility to Deal with Family Matters ${ }^{17}$

Work Interferes with Family ${ }^{18}$
"How satisfied are you in your main job?"

"My job is interesting."

"I can work independently."

"In my job I can help other people."

"My job is useful to society."

"My income is high."

"My job is secure."

"My opportunities for advancement are high."

"How often do you have to do hard physical work?"

"How often do you find your work stressful?"

"In general, how would you describe relations at your workplace between management and employees?"

"In general, how would you describe relations at your workplace between workmates/colleagues?"

"In my job, I have personal contact with others."

"Over the past 5 years, have you been discriminated against with regard to work, for instance, when applying for a job, or when being considered for a pay increase or promotion?"

"Over the past 5 years, have you been harassed by your supervisors or coworkers at your job, for example, have you experienced any bullying, physical, or psychological abuse?"

"How often do you work at home during your normal work hours?

"How often does your job involve working weekends?

"Which of the following best describes how your working

hours are decided (times you start and finish your work)?

"How difficult would it be for you to take an hour or two off during work hours, to take care of personal or family matters?

"How often do you feel that the demands of your job interfere with your family?"

\section{Control Variables}

As indicated by Westover (2012b, p. 17) "the literature has identified many important individual control variables, due to limitations in data availability, control variables used for the quantitative piece of this study will be limited to the following individual characteristics: (1) Sex ${ }^{19}$, (2) Age $^{20}$, (3) Years of Education $^{21}$, (4) Marital Status ${ }^{22}$, and (5) Size of Family ${ }^{23}$ (see Carlson \& Mellor 2004; Hammermesh, 
1999; Hodson, 2002; Souza-Poza \& Souza-Poza, 2000)" (2012b, p. 17). Additionally, control variables used in this analysis include: (1) Work Hours ${ }^{24}$, (2) ISCO Job Classification ${ }^{25}$, (3) Supervisory Status ${ }^{26}$, (4) Employment Relationship ${ }^{27}$, and (5) Public/Private Organization ${ }^{28}$ (see Hammermesh, 1999; SouzaPoza \& Souza-Poza, 2000).

\section{Statistical Methodology}

We analyzed work orientation and job satisfaction data from individual respondents in the 37 countries included in the 2015 Work Orientations wave of the International Social Survey Program. Analyzing data from respondents in 37 countries around the globe, we first ran the appropriate bivariate and multivariate analyse ${ }^{29}$ on all key study variables in order to make comparisons. Next, we ran an Ordinary Least Squares Regression (OLS) regression for all main study variables and respondents in all countries, followed by country-specific OLS regression models ${ }^{30}$.

\section{RESULTS}

\section{Descriptive Results}

Figure 2 below shows mean job satisfaction levels across the 37 countries included in the 2015 wave of ISSP Work Orientations data. Of note is the general variation across countries and regions of the world. The highest job satisfaction levels are in Venezuela, Switzerland, Austria, and Mexico (means between 5.7-5.9), while most countries have a mean job satisfaction scores in the 5.2-5.4 range (overall world-wide mean is 5.3). Poland, China, and Japan have the lowest mean job satisfaction scores (means between 4.5-4.8).

\section{FIGURE 2}

\section{MEAN JOB SATISFACTION, BY COUNTRY}

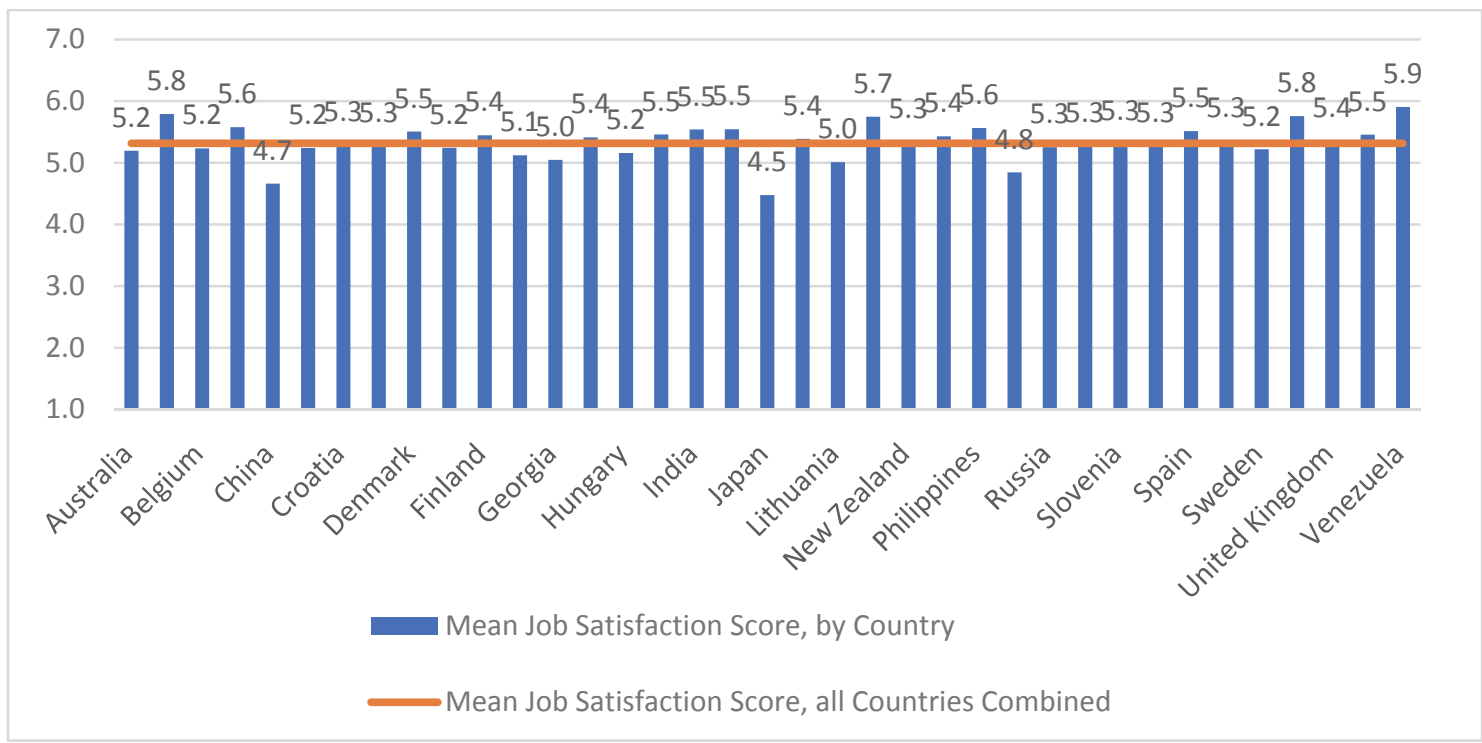

Additionally, Table 2 shows the comparative means of main study variables, by for-profit and nonprofit jobs shows a significant difference in mean job satisfaction scores between employees in forprofit (5.27) and nonprofit (5.39) employees, with significant difference in the mean scores of several of the intrinsic job characteristics as well ${ }^{31}$. In particular, "interesting work," "help others," "job useful to society," and "job security" mean scores are all significantly higher for nonprofit employees than those for for-profit employees. Additionally, "contact with others," "work weekends," and "flexibility to deal 
with family matters" means are also significantly higher for nonprofit employees that for for-profit employees. Only "physical effort" is significantly higher for for-profit employees.

TABLE 2

\section{MEAN SCORES OF JOB SATISFACTION AND MAIN STUDY VARIABLES} BY FOR-PROFIT/NONPROFIT EMPLOYMENT, 2015

\begin{tabular}{|l|c|c|c|}
\hline & & & \\
& & \\
& & \\
VARIABLE & & & \\
\hline Job Satisfaction & 5.27 & 5.39 & 5.32 \\
\hline Interesting Work & 3.75 & 4.01 & 3.83 \\
Job Autonomy & 3.79 & 3.81 & 3.82 \\
Help Others & 3.74 & 4.19 & 3.88 \\
Job Useful to Society & 3.79 & 4.29 & 3.94 \\
\hline Job Security & 3.68 & 3.96 & 3.77 \\
Pay & 2.83 & 2.79 & 2.82 \\
Promotional Opportunities & 2.76 & 2.76 & 2.78 \\
Physical Effort & 2.75 & 2.47 & 2.71 \\
Work Stress & 3.13 & 3.26 & 3.17 \\
\hline Relations with Coworkers & 4.19 & 4.18 & 4.19 \\
Relations with Management & 3.92 & 3.85 & 3.91 \\
Contact with Others & 4.16 & 4.38 & 4.23 \\
Discriminated Against at Work & 1.82 & 1.81 & 1.82 \\
Harassed at Work & 1.87 & 1.83 & 1.86 \\
\hline Work from Home & 4.02 & 3.96 & 4.00 \\
Work Weekends & 3.07 & 3.33 & 3.14 \\
Schedule Flexibility & 1.67 & 1.51 & 1.63 \\
Flexibility to Deal with Family & 2.20 & 2.38 & 2.25 \\
Matters & 3.68 & 3.60 & 3.66 \\
Work Interferes with Family & 42.86 & 44.65 & 43.37 \\
\hline Age & 13.01 & 14.38 & 13.34 \\
Education & 3.29 & 3.22 & 3.23 \\
Size of Family & 42.07 & 38.43 & 40.96 \\
Work Hours & $70.54 \%$ & $29.46 \%$ & $100 \%$ \\
\% of Respondents in Category & & & \\
\hline
\end{tabular}

\section{Regression Models}

Following the approach of Andrade and Westover (2018a, 2018b), a step-wise regression approach was used to build the OLS model (see Table 3 below). Model 1 includes all control variables. Models 1 through 4 each look specifically at the different categories of variables (intrinsic, extrinsic, work relations, and work-life balance independent variables). Finally, the combined model includes all key independent 
variables (intrinsic, extrinsic, work relations, and work-life balance) and the control variables on job satisfaction. Nearly all variables were statistically significant $(\mathrm{p}<.001)$ when the individual base model and models 1-4 were run, with the exception of size of family and working weekends. However, in the combined model, working weekends was significant, while physical effort, contact with others, working from home, and several individual control variables were not significant. We can see variation in adjusted r-squared values for the base controls model and Model 1-4 and the combined model with all intrinsic, extrinsic, work relations, work-life balance, and control variables accounted for nearly $43 \%$ of the variation in job satisfaction (adjusted $r$-squared $=0.428$ ).

Finally, the above specified combined model was then run for each individual country included in the ISSP 2015 wave (full regression results by country are available upon request). As can be seen in Figure 3 (and full regression results by For-Profit/Nonprofit Employment in Table 4), there is a great deal of variation between countries in standardized beta coefficient statistical significance for each of the intrinsic, extrinsic, work relations, and work-life balance job characteristics and control variables in predicting job satisfaction. While extrinsic, work-life balance (with the exception of flexibility to deal with family matters), and control variables (with the exceptions of marital status and gender) were mostly consistent in significance and direction for both for-profit and nonprofit employees, there was variation in the intrinsic and work relations job characteristics. More specifically, "helping others" is significant for nonprofit employees but not for-profit employees, "autonomy" and "job useful to society" are significant for for-profit employees but not for nonprofit employees, and "contact with others" is significant for forprofit but not for nonprofit employees. 


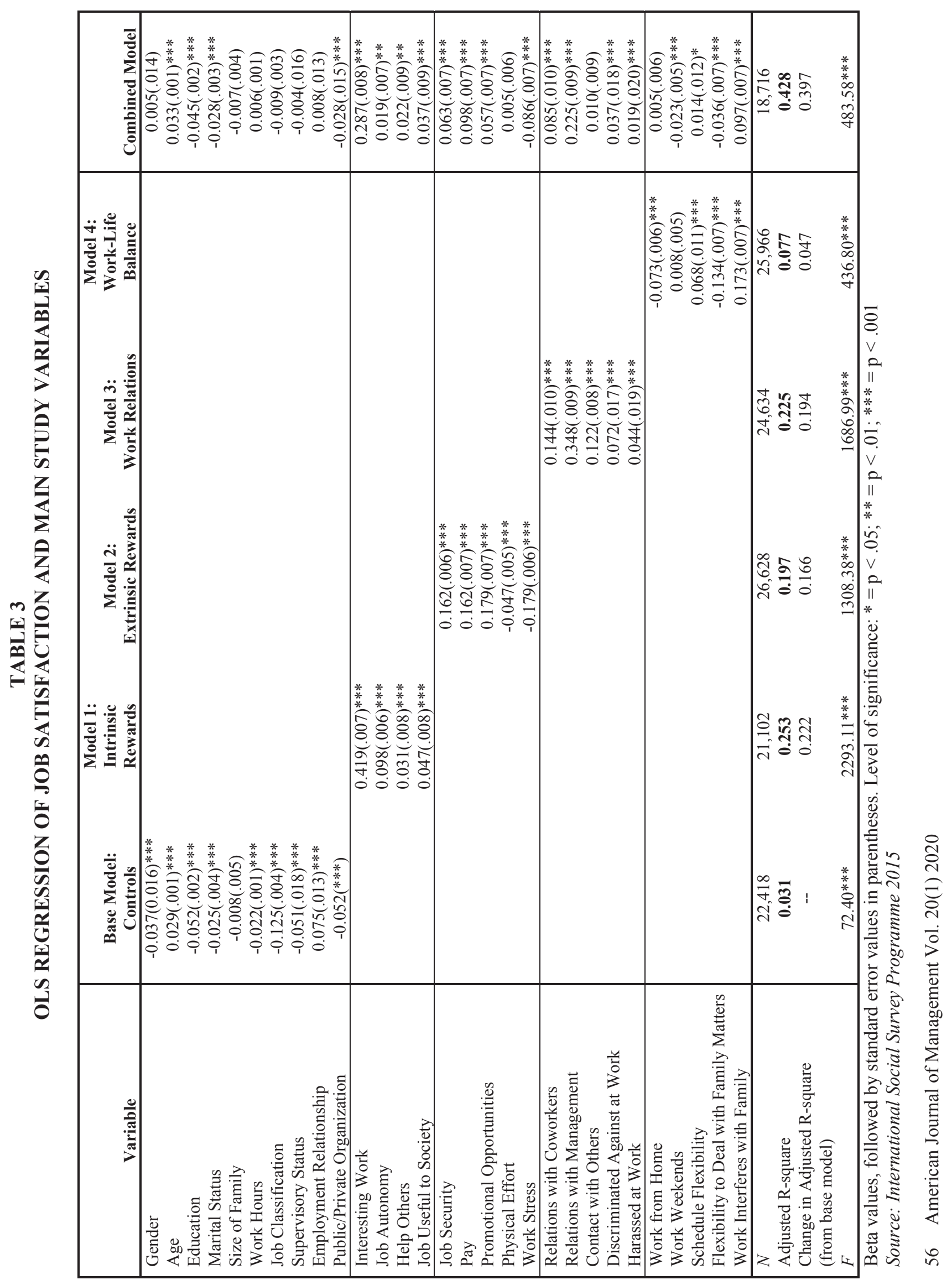


FIGURE 3

MODEL FIT: JOB SATISFACTION MODEL ADJUSTED R-SQUARED, BY COUNTRY

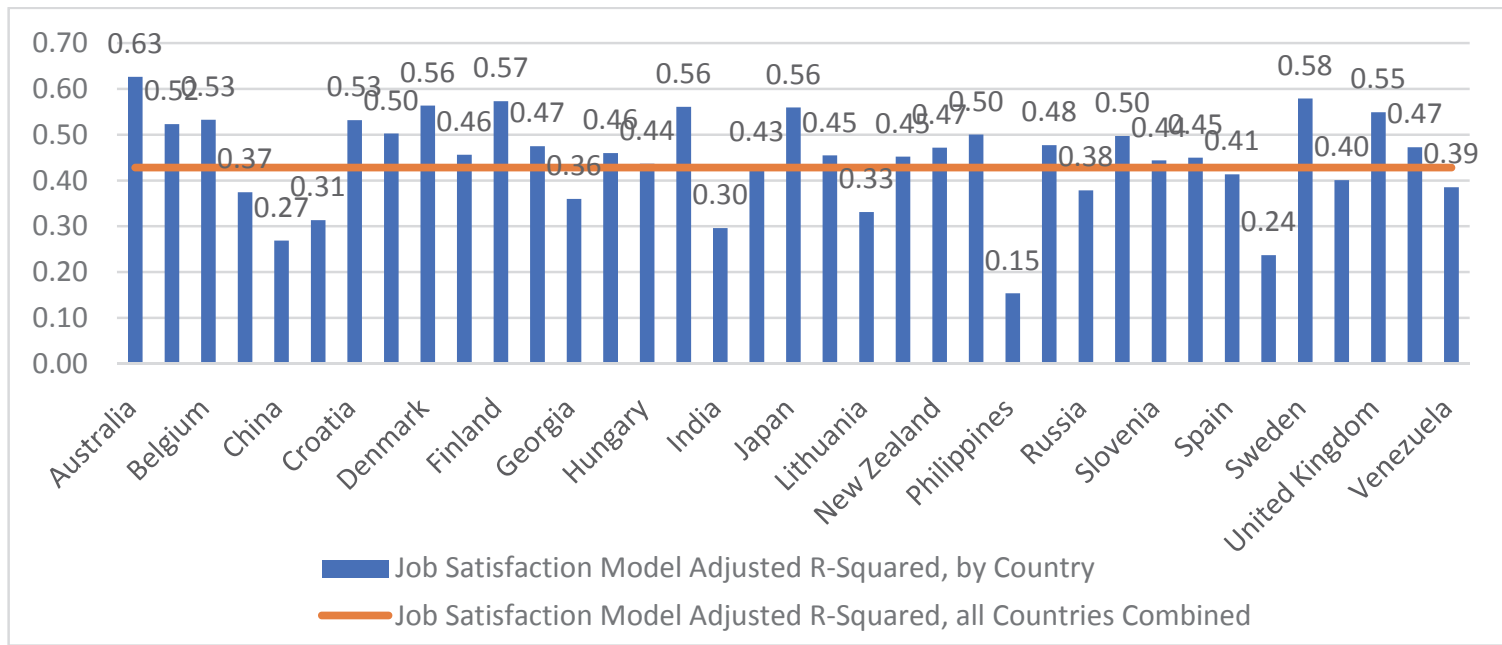

TABLE 4

REGRESSION RESULTS OF JOB SATISFACTION AND MAIN STUDY VARIABLES, BY GENDER

\begin{tabular}{|c|c|c|c|}
\hline VARIABLE & 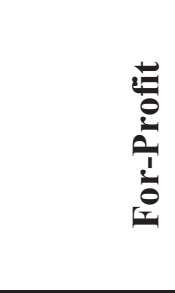 & 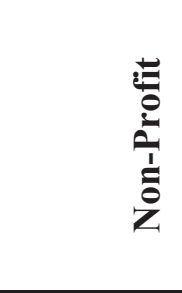 & 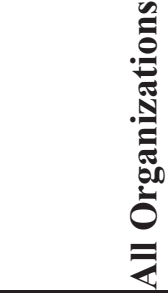 \\
\hline Interesting Work & $0.263 * * *$ & $0.328 * * *$ & $0.287 * * *$ \\
\hline Job Autonomy & $0.026^{* *}$ & 0.010 & $0.019 * *$ \\
\hline Help Others & 0.011 & $0.033^{*}$ & $0.022 * *$ \\
\hline Job Useful to Society & $0.044 * * *$ & 0.013 & $0.037 * * *$ \\
\hline Job Security & $0.073 * * *$ & $0.036 * *$ & $0.063 * * *$ \\
\hline Pay & $0.098 * * *$ & $0.097 * * *$ & $0.098 * * *$ \\
\hline Promotional Opportunities & $0.051 * * *$ & $0.061 * * *$ & $0.057 * * *$ \\
\hline Physical Effort & 0.003 & 0.010 & 0.005 \\
\hline Work Stress & $-0.088 * * *$ & $-0.087 * * *$ & $-0.086 * * *$ \\
\hline Relations with Coworkers & $0.080 * * *$ & $0.107 * * *$ & $0.085^{* * *}$ \\
\hline Relations with Management & $0.236 * * *$ & $0.209 * * *$ & $0.225^{* * *}$ \\
\hline Contact with Others & $0.018 *$ & -0.009 & 0.010 \\
\hline Discriminated Against at Work & $0.031 * * *$ & $0.029 *$ & $0.037 * * *$ \\
\hline Harassed at Work & $0.018 *$ & $0.032 * *$ & $0.019 * * *$ \\
\hline Work from Home & 0.009 & -0.004 & 0.005 \\
\hline Work Weekends & $-0.022 * *$ & $-0.033 * *$ & $-0.023 * * *$ \\
\hline Schedule Flexibility & 0.012 & 0.019 & $0.014 *$ \\
\hline
\end{tabular}




\begin{tabular}{|l|cc|c|}
\hline Flexibility to Deal with Family & $-0.041 * * *$ & -0.018 & $-0.036 * * *$ \\
Matters & $0.088^{* * *}$ & $0.127 * * *$ & $0.097 * * *$ \\
\hline Work Interferes with Family & -0.002 & $0.025^{*}$ & 0.005 \\
Gender & $0.034 * * *$ & $0.041 * * *$ & $0.033 * * *$ \\
Age & $-0.040^{* * *}$ & $-0.048^{* * *}$ & $-0.045^{* * *}$ \\
Education & $-0.029 * * *$ & -0.014 & $-0.028 * * *$ \\
Marital Status & -0.003 & 0.007 & -0.007 \\
Work of Family & -0.002 & 0.014 & 0.006 \\
Job Classification & -0.009 & -0.021 & -0.009 \\
Supervisory Status & -0.010 & 0.003 & -0.004 \\
Employment Relationship & 0.009 & 0.013 & 0.008 \\
Public/Private Organization & $-0.016 *$ & $-0.031 * *$ & $-.028 * * *$ \\
\hline$N$ & 11,956 & 5,083 & 18,716 \\
ADJ. R-SQUARED & $\mathbf{0 . 4 2 9}$ & $\mathbf{0 . 4 0 1}$ & $\mathbf{0 . 4 2 8}$ \\
$F$ & $310.20^{* * *}$ & $121.08 * * *$ & $483.58 * * *$ \\
\hline
\end{tabular}

Beta Values; Level of significance: $*=\mathrm{p}<.05 ; * *=\mathrm{p}<.01 ; * * *=\mathrm{p}<.001$

\section{REVISITING HYPOTHESES AND FUTURE RESEARCH}

To test global differences in job satisfaction levels and its determinants for for-profit and nonprofit employees, Table 2 shows a statistically significant difference in mean job satisfaction scores between for-profit and nonprofit employees in the entire global sample, with significant difference in several of the intrinsic, extrinsic, work relations, and work-life balance job characteristics. Additionally, Table 4 shows OLS regression results for for-profit and nonprofit employees separately and demonstrates only minor variation in standardized beta coefficient strength and statistical significance between the two groupings for intrinsic, extrinsic, work relations, and work-life balance characteristics.

Therefore, $\mathrm{H} 1$ is supported by these results, namely that there are consistent statistically significant differences in job satisfaction levels across countries for for-profit and nonprofit employees, the forprofit/nonprofit control variable was not statistically significant in the OLS regression model. Furthermore, H2a is not supported by these results, namely, there is no statistical difference between the saliency of extrinsic job factors on the job satisfaction of for-profit and nonprofit employees (with little difference in standardized beta coefficient strength and statistical significance between the two groupings). $\mathrm{H} 2 \mathrm{~b}$ is partially supported, in that "Help Others" is statistically significant for nonprofit employees and not for for-profit employees, but unexpectedly, "job useful to society" and "job autonomy" were only significant for for-profit employees and not for nonprofit employees ("interesting work" was roughly the same for both groups of employees). Interestingly, contrary to what was expected from the literature, $\mathrm{H} 2 \mathrm{c}$ and $\mathrm{H} 2 \mathrm{~d}$ are not strongly supported by the data, though there is some minor variation between for-profit and nonprofit employees.

\section{DISCUSSION}

The findings of this study offer some support for previous research on job satisfaction for for-profit and nonprofit employees, particularly related to the importance of intrinsic motivation (Buelens \& Van den Broeck, 2007; Borzaga \& Tortia, 2006; Boyne, 2002; Leete, 2000; Lewis \& Frank, 2002; Light, 2002; Liu \& Tang, 2011; Melnick, Petralla, \& Richez-Battesti, 2013; Narcy, 2011). Elements associated with intrinsic motivation such as helping others, being useful to society, and enjoying interesting work 
were more salient based on comparative means for those in nonprofits than those in for-profits across the 37 countries in the study, demonstrating the significance of this factor globally.

However, further statistical analyses found that "autonomy" and "job useful to society" were more significant for for-profit employees than nonprofit employees as was "contact with others," elements which are generally associated with nonprofit employees (Houston, 2000; Jurkiewicz \& Massey, 1997; Karl \& Sutton, 1998; Mirvis \& Hackett, 1983). Additionally, "having job security" was more relevant to nonprofit than for-profit workers, another contradiction to previous research (Benz, 2005; Borzaga \& Depedri, 2005; Cohen, 2010; Frank, 1996; Sen, 1985). In terms of extrinsic motivation and work-life balance factors (with some exceptions), findings were mostly consistent in statistical significance and direction for both for-profit and nonprofit employees. These findings largely contradict previous research, which favors factors such as autonomy, societal contributions, and connections with others as playing a larger role in job satisfaction for nonprofit workers than for-profit workers.

The findings of this study perhaps indicate more commonalities than differences in job satisfaction factors for workers in for-profit and nonprofit organizations across countries. One explanation for this is that individuals are most likely attracted to work environments that match their values and preferred work conditions. When this match does not occur, workers are likely to transfer to a different organization. Thus, when workers find a good match, they demonstrate high levels of satisfaction.

In all cases, managers should consider how to encourage motivation as well as enhance work-life balance and work relations in order to realize the benefits of a satisfied workforce. Control over one's work, flexibility, and variety lead to motivation, and consequently, to innovation, creativity, and proactive performance (Garg \& Rastogi, 2006). Managers should also be aware of stress and burnout factors, which may lead to heavier workloads and turnover in spite of high levels of satisfaction (Hamaan \& Foster, 2014; Kang, Huh, Cho, \& Auh, 2014; Kim \& Lee, 2007; Light, 2003; Mirvis \& Hackett, 1983). In all cases, poor job quality conditions can lead to increased turnover (Ban, Drahnak-Faller, \& Tower, 2003; Brown \& Yoshioka, 2003; Kang, Huh, Cho, \& Auh, 2014; Kim \& Lee 2007; Selander \& Ruuskanen, 2016).

In sum, findings in this study departed somewhat from those of previous research, indicating more of a blurring of factors impacting job satisfaction for for-profit and nonprofit workers rather than distinct differences. While employees will seek working conditions that best match with their values and experiences, employers need to focus on ways to encourage motivation and offer positive working conditions and opportunities.

\section{ENDNOTES}

1. ISSP Researchers collected the data via self-administered questionnaires, personal interviews, and mailback questionnaires, depending on the country. For a full summary and description of this research, see https://www.gesis.org/issp/modules/issp-modules-by-topic/work-orientations/2015/.

2. Countries include, in alphabetical order: Australia, Austria, Belgium, Chile, China, Taiwan, Croatia, Czech Republic, Denmark, Estonia, Finland, France, Georgia, Germany, Hungary, Iceland, India, Israel, Japan, Latvia, Lithuania, Mexico, New Zealand, Norway, Philippines, Poland, Russia, Slovak Republic, Slovenia, South Africa, Spain, Suriname, Sweden, Switzerland, United Kingdom, United States, Venezuela

3. Each variable is a single-item indicator.

4. Response categories for this variable include: (1) Completely Dissatisfied, (2) Very Dissatisfied, (3) Fairly Dissatisfied, (4) Neither Satisfied nor Dissatisfied, (5) Fairly Satisfied, (6) Very Satisfied, (7) Completely Satisfied.

5. Response categories for these variables include: (1) Strongly Disagree, (2) Disagree, (3) Neither Agree nor Disagree, (4) Agree, and (5) Strongly Agree.

6. Response categories for these variables include: (1) Strongly Disagree, (2) Disagree, (3) Neither Agree nor Disagree, (4) Agree, and (5) Strongly Agree.

7. Response categories for this variable include: (1) Always, (2) Often, (3) Sometimes, (4) Hardly Ever, (5) Never. 
8. Response categories for this variable include: (1) Always, (2) Often, (3) Sometimes, (4) Hardly Ever, (5) Never.

9. Response categories for these variables include: (1) Very Bad, (2) Bad, (3) Neither good nor bad, (4) Good, and (5) Very Good.

10. Response categories for these variables include: (1) Very Bad, (2) Bad, (3) Neither good nor bad, (4) Good, and (5) Very Good.

11. Response categories for these variables include: (1) Strongly Disagree, (2) Disagree, (3) Neither Agree nor Disagree, (4) Agree, and (5) Strongly Agree.

12. Response categories for these variables include: (1) Yes, (2) No.

13. Response categories for these variables include: (1) Yes, (2) No.

14. Response categories for this variable include: (1) Always, (2) Often, (3) Sometimes, (4) Hardly Ever, (5) Never.

15. Response categories for this variable include: (1) Always, (2) Often, (3) Sometimes, (4) Hardly Ever, (5) Never.

16. Response categories for this variable include: (1) Starting and finishing times are decided by my employer and I cannot change them on my own,

17. Response categories for this variable include: (1) Not difficult at all, (2) Not too difficult, (3) Somewhat difficult, and (4) Very difficult.

18. Response categories for this variable include: (1) Always, (2) Often, (3) Sometimes, (4) Hardly Ever, (5) Never.

19. Categories for this variable include: (1) Male, (2) Female.

20. Continuous variable.

21. Continuous variable.

22. Response categories for this variable include: (1) married, (2) civil partnership, (3) separated from spouse/civil partner(s), (4) divorced from spouse/ legally separated, (5) widowed/ civil partner died, (6) never married/ never in a civil partner

23. Continuous variable.

24. Continuous variable.

25. Categories for this variable include: (1) Managers, (2) Professionals, (3) Technicians and Associate Professionals, (4) Clerical Support Workers, (5) Services and Sales Workers, (6) Skilled Agricultural, Forestry and Fishery Workers, (7) Craft and Related Trades Workers, (8) Plant and Machine Operators and Assemblers, (9) Elementary Occupations, and (10) Armed Forces Occupations

26. Categories for supervising others: (1) Yes, (2) No.

27. Categories for this variable include: (1) Employee, (2) self-employed without employees, (3) self-employed with employees, and (4) working for own family's business.

28. Categories for type of organization: (1) Public, (2) Private

29. All correlations, cross-tabulations, ANOVA, ANCOVA, post-hoc tests, and full descriptive statistics have not been included here due to space limitations, but are available upon request. Additionally, appropriate tests for multicollinearity were conducted. There are no issues with mutlicollinearity of variables in the OLS model. Additionally, all outliers were Winsorized in the initial data cleaning stages, prior to final models and analysis.

30. Due to the ordinal nature of the dependent variable, it is most appropriate to use an ordered probit regression to look at the effect of different job characteristics on one's overall job satisfaction. However, many researchers have argued that using OLS regression is appropriate when looking at satisfaction variables on a Likert scale, where most respondents understand that the difference between responses of 1 and 2 is the same as the difference between responses of 2 and 3, and so on. Additionally, using OLS regression results allows us to report an $\mathrm{r}$-squared and adjusted $\mathrm{r}$-squared value for the model and compare coefficients across models, which comparison is not appropriate in a probit model. Therefore, all regression results reported herein are OLS regression result. It is important to note that when the same OLS models where run in an ordered probit regression, the same significant results appeared for each of the independent and control variables across countries and waves (full ordered probit model results, are available upon request).

31. Descriptive results by country are available upon request. 


\section{REFERENCES}

Allen, J., \& Van Der Velden, R. (2001). Educational mismatches versus skill mismatches: Effects on wages, job satisfaction, and on-the-job search. Oxford Economic Papers, 53(3), 434-452. doi:10.1093/oep/53.3.434.

Andrade, M. S., \& Westover, J. H. (2018a). Generational differences in work quality characteristics and job satisfaction. Evidence-based HRM, 6(3), 287-304.

Andrade, M. S., \& Westover, J. H. (2018b). Revisiting the impact of age on job satisfaction: A global comparative examination. The Global Studies Journal, 1(4), 1-24.

Appelbaum, S., \& Kamal, R. (2000). An analysis of the utilization and effectiveness of nonfinancial incentives in small business. Journal of Management Development, 19(9), 733-763.

Baldwin, N. J. (1991). Public versus private employees: Debunking stereotypes. Review of Public Personnel Administration, 11(1-2), 1-27.

Balfour, D. L., \& Wechsler, B. (1991). Commitment, performance, and productivity in public organizations. Public Productivity and Management Review, 14(4), 355-367.

Ban, C., Drahnak-Faller, A., \& Tower, M. (2003). Human resource challenges in human Service and community development organizations: recruitment and retention of professional staff. Review of Public Personnel Administration, 23(2), 133-153. doi: http://dx.doi.org/10.1177/0734371X03023002004

Becchetti, L., Castriota, S., \& Depedri, S. (2013). Working in the for-profit versus not-for-profit sector: What difference does it make? An inquiry on preferences of voluntary and involuntary movers. Industrial and Corporate Change, 23(4), 1087-1120.

Beechler, S. (2013). The role of leaders in helping others find meaning at work. Retrieved from http://knowledge.insead.edu/blog/insead-blog/ the-role-of-leaders-in-helping-others-findmeaning-at-work-3055\# qeqIPscmeki3Gclq.99

Benz, M. (2005). Not of the profit, but for the satisfaction? Evidence on worker well-being in non-profit firms. Kyklos, 58(2), 155-176.

Blau, G. (1994). Developing and testing a taxonomy of lateness behavior. Journal of Applied Psychology, 79, 959-70.

Borzaga, C., \& Depedri, S. (2005). Interpersonal relations and job satisfaction: Some empirical results in social and community care services. In B. Gui \& R. Sugden (Eds), Economics and social interaction: Accounting for interpersonal relations (pp. 132-153). Cambridge: Cambridge University Press.

Borzaga, C., \& Tortia, E. (2006). Worker motivations, job satisfaction, and loyalty in public and nonprofit social services. Nonprofit and Voluntary Sector Quarterly, 35(2), 225-248. doi:10.1177/0899764006287207

Boyne, G. A. (2002). Public and private management: What's the difference? Journal of Management Studies, 39(1), 97-122.

Brandi, S. (2012). Are South African NGOs employers of choice or necessity? Retrieved from http://www.ngopulse.org/article/are-south-african-ngos-employers-choice-or-necessity

Brown, W., \& Yoshioka, C. (2003). Mission attachment and satisfaction as factors in employee Retention. Nonprofit Management \& Leadership, 14(1), 5-18. doi: http://dx.doi.org/10.1002/nml.18

Buelens, M., \& Van den Broeck, H. (2007). An analysis of differences in work motivation between public and private sector organizations. Public Administration Review, 67(1), 65-74.

Butler, A. (2009). Wages in the nonprofit sector: Healthcare, personal care, and social service occupations. Washington, DC: U.S. Bureau of Labor Statistics. Retrieved from https://www.bls.gov/opub/mlr/cwc/wages-in-the-nonprofit-sector-healthcare-personal-care-andsocial-service-occupations.pdf

Cohen, R. (2010). Nonprofit salaries: Achieving parity with the private sector. Retrieved from https://nonprofitquarterly.org/2010/06/21/nonprofit-salaries-achieving-parity-with-the-privatesector/ 
Crewson, P. E. (1997). Public service motivation: Building empirical evidence of incidence and effect. Journal of Public Administration Research and Theory, 74(4), 499-518.

Gabris, G. T., \& Simon, S. (1995). Public sector motivation as an independent variable affecting career decisions. Public Personnel Management, 24(1), 33-51.

Garg, P., \& Rastogi, R. (2006). New model of job design: Motivating employees’ performance. Journal of Management Development, 25(6), 572-587. http://doi.org/10.1108/02621710610670137

Garrido, M. J., Perez, P., \& Anton, C. (2005). Determinants of sales manager job satisfaction: An analysis of Spanish industrial firms. International Journal of Human Resource Management, 16(1), 19341954.

Goulet, L. R., \& Frank, M. L. (2002). Organizational commitment across three sectors: Public, non-profit, and for-profit. Public Personnel Management, 31(2), 201-210.

Hamaan, D. J., \& Foster, N. T. (2014). An exploration of job demands, job control, stress, and attitudes in public, nonprofit, and for-profit employees. Review of Public Personnel Administration, 34(4), 332-355. DOI: $10.1177 / 0734371 X 13491119$

Hansmann, H. B. (1980). The role of nonprofit enterprise. Yale Law Journal, 89, 835-901.

Herzberg, F. (1966). Work and the nature of man. Cleveland, OH: The World Publishing Company.

Herzberg, F. (1968). One more time: How do you motivate employees? Harvard Business Review, 46(1), $53-62$.

Houston, D. J. (2000). Public service motivation: A multivariate test. Journal of Public Administration Research and Theory, 10(4), 713-727.

Jurkiewica, C. L. (2000). Generation X and the public employee. Public Personnel Management, 29(1), 55-67.

Jurkiewicz, C. L., \& Massey, T. K. (1997). What motivates municipal employees: A comparison study of supervisory vs. non-supervisory personnel. Public Personnel Management, 26(3), 367-376.

Kacmar, M., Carlson, D. S., \& Brymer, R. A. (1999). Antecedents and consequences of organizational commitment: A comparison of two scales. Educational and Psychological Measurement, 59(6), 967-994.

Kalleberg, A. L., Marsden, P. V., Reynolds, J., \& Knoke, D. (2006). Beyond profit? Sectoral differences in high-performance work practices. Work and Occupations, 33, 271-302.

Kang, C., Huh, S., Cho, S., \& Auh, E. Y. (2015). Turnover and retention in nonprofit employment: The Korean college graduates' experience. Nonprofit and Voluntary Sector Quarterly, 44(4), 641664. doi: http://dx.doi.org/10.1177/0899764014553032

Karl, K. A., \& Sutton, C. L. (1998). Job values in today's workforce: A comparison of public and private sector employees. Public Personnel Management, 27(4), 515-527.

Kim, S., \& Lee, J. (2007). Is mission attachment an effective management tool for employee retention? An empirical analysis of a nonprofit human services agency. Review of Public Personnel Administration, 27(3), 227-248. doi: http://dx.doi.org/10.1177/0734371X06295791

Lanfranchi, J., Narcy, M., \& Larguem, M. (2009). Would you accept this job? An evaluation of the decision utility of workers in the for-profit and nonprofit sectors. Munich Personal RePEc Archive. Retrieved from https://mpra.ub.uni-muenchen.de/16359/1/MPRA_paper_16359.pdf

Lee, T. (1998). Job satisfaction leads to turnover. Journal of Business and Psychology, 2, 263-271.

Lee, Y. J., \& Sabharwal, M. (2016). Education-job match, salary, and job satisfaction across the public, non-profit, and for-profit sectors: Survey of recent college graduates. Public Management Review, 18(1), 40-65. http://dx.doi.org/10.1080/14719037.2014.957342

Lewis, G. B., \& Frank, S. A. (2002). Who wants to work for the government? Public Administration Review, 62(4), 395- 404. doi:10.1111/0033-3352.00193

Leete, L. (2000). Wage equity and employee motivation in nonprofit and for-profit organizations. Journal of Economic Behavior \& Organization, 43, 423-446. 
Light, P. C. (2003). The health of the human services workforce. Center for Public Service, Brookings Institution. Retrieved from https://www.brookings.edu/research/the-health-of-the-humanservices-workforce/

Liu, B., \& Tang, T. (2011). Does the love of money moderate the relationship between public service motivation and job satisfaction? The case of Chinese professionals in the public sector. Public Administration Review, 71(5), 718-727. doi:10.1111/j.1540-6210.2011.02411.x

Melnick, E., Petrella, F., \& Richez-Battesti, N. (2013). Does the professionalism of management practices in nonprofits and for-profits affect job satisfaction? The International Journal of Human Resource Management, 24(6), 1300-1321. http://dx.doi.org/10.1080/09585192.2012.712543

Mirvis, P. H., \& Hackett, E. J. (1983). Work and work force characteristics in the nonprofit sector. Monthly Labor Review, 116(4), 3-12.

Moon, M. J. (2000). Organizational commitment revisited in new public management: Motivation, organizational culture, and managerial level. Public Performance and Management Review, 24(2), 177-194.

Munoz de Bustillo Llorente, R., \& Macias, E. F. (2005). Journal of Behavioral and Experimental Economics, 34(5), 656-673.

Narcy, M. (2011). Would nonprofit workers accept to earn less? Evidence from France. Applied Economics, 43(3), 313-326. doi:10.1080/00036840802570447.

Perry, J. L. (1996). Measuring public service motivation: An assessment of construct reliability and validity. Journal of Public Administration Research and Theory, 6(1), 5-22.

Perry, J. L. (1997). Antecedents of public service motivation. Journal of Public Administration Research and Theory, 7(2), 181-197.

Perry, J. L. (2000). Bringing society in: Toward a theory of public service motivation. Journal of Public Administration Research and Theory, 10(2), 471-488.

Perry J. L., \& Wise, L. R. (1990). The motivational bases of public service. Public Administrative Review, 50(3), 367-373.

Rainey, H. G. (1989). Public management: Recent research on the political context and managerial roles, structures, and behaviors. Journal of Management, 15(2), 229-250.

Renard, M., \& Snelgar, R. J. (2016). How can work be designed to be intrinsically rewarding? Qualitative insights from South African non-profit employees. SA Journal of Industrial Psychology, 42(1). http://dx.doi. org/10.4102/sajip.v42i1.1346

Ruhm, C. J., \& Borkowski, C. (2003). Compensation in the nonprofit sector. Journal of Human Resources, 38(4), 992-1021.

Ryan, R. M., \& Deci, E. L. (2000). Self-determination theory and the facilitation of intrinsic motivation, social development, and well-being. The American Psychologist, 55(1), 68-78.

Selden, S., \& Sowa, J. E. (2011). Performance management and appraisal in human service organizations: Management and staff perspectives. Public Personnel Management, 40(3), 251-265.

Tietjen, M. A., \& Myers, R. M. (1998). Motivation and job satisfaction. Management Decision, 36(4), 226-231.

Weisbrod, B. A. (1998). To profit or not to profit: The commercial transformation of the nonprofit sector. New York: Cambridge University Press.

Vila, L., \& García-Mora, B. (2005). Education and the determinants of job satisfaction. Education Economics, 13(4), 409-425. doi:10.1080/09645290500251730.

Westover, J. H. (2012a). Comparative international differences in intrinsic and extrinsic job quality characteristics and worker satisfaction, 1989-2005. International Journal of Business and Social Science, 3(7), 1-15.

Westover, J. H. (2012b). Comparative welfare state impacts on work quality and job satisfaction: A crossnational analysis. International Journal of Social Economics, 39(7), 502-525. https://doi.org/10.1108/03068291211231687

Zeffane, R. (1994). Patterns of organizational commitment and perceived management style: A comparison of public and private sector employees. Human Relations, 47(3), 977-1010. 